\title{
Front Matter: Volume 11456
}

, "Front Matter: Volume 11456," Proc. SPIE 11546, Advanced Laser Processing and Manufacturing IV, 1154601 (30 October 2020); doi: $10.1117 / 12.2586007$

SPIE. Event: SPIE/COS Photonics Asia, 2020, Online Only 


\title{
PRO CEEDINGS OF SPIE
}

\section{Advanced Laser Processing and Manufacturing IV}

\author{
Rongshi Xiao \\ Minghui Hong \\ Jianhua Yao \\ Yuji Sano \\ Editors
}

\section{2-16 October 2020 \\ Online Only, China}

Sponsored by

SPIE

COS-Chinese Optical Society

Cooperating Organizations

Tsinghua University (China) - Peking University (China) - University of Science and Technology of China (China) - Zhejia ng University (China) • Tianjin University (China) • Beijing Institute of Tec hnology (China) • Beijing University of Posts a nd Telecommunic a tions (China) - Nankai University (China) - Changchun University of Science and Technology (China) - University of Shanghai for Science and Technology (China) • Capital Nomal University (China) • Huazhong University of Science and Technology (China) • Beijing J ia otong University (China) $\bullet$ China J iliang University (China) - Shanghai Institute of Optic s and Fine Mechanic s, CAS (China) • Changchun Institute of Optics, Fine Mechanic sand Physics, CAS (C hina) • Institute of Semic onductors, CAS (China) - Institute of Optics and Electronic S, CAS (China) • Institute of Physics, CAS (China) - Shanghai Institute of Technical Physics, CAS (China) - China Instrument and Control Society (China) - Japan Optical Society (J apan) - Korea Optic al Society (Korea, Republic of) - Austra lia Optical Soc iety (Austra lia) • Singa pore Optic al Soc iety (Singapore) • European Optic al Soc iety

Supporting Organizations China Association for Science and Technology (CAST) (China)

Department of Information of National Nature Science Foundation (NSFC) (China)

Published by

SPIE

Volume 11546 
The papers in this volume were part of the technical conference cited on the cover and title page. Papers were selected and subject to review by the editors and conference program committee. Some conference presentations may not be available for publication. Additional papers and presentation recordings may be available online in the SPIE Digital Library at SPIEDigita lLibra ry.org.

The papers reflect the work and thoughts of the authors and are published herein as submitted. The publisher is not responsible for the validity of the information or for any outcomes resulting from reliance thereon.

Please use the following format to cite material from these proceedings:

Author(s), "Title of Paper," in Advanced Laser Processing and Manufacturing IV, edited by Rongshi Xiao, Minghui Hong, J ianhua Yao, Yuji Sano, Proceedings of SPIE Vol. 11546 (SPIE, Bellingham, WA, 2020) Seven-digit Artic le CID Number.

ISSN: 0277-786X

ISSN: 1996-756X (electronic)

ISBN: 9781510639072

ISBN: 9781510639089 (electronic)

Published by

SPIE

P.O. Box 10, Bellingham, Washington 98227-0010 USA

Telephone +1 3606763290 (Pacific Time)· Fax +1 3606471445

SPIE.org

Copyright (c) 2020, Society of Photo-Optic al Instrumentation Engineers.

Copying of material in this book for intemal or personal use, or for the intemal or personal use of specific clients, beyond the fair use provisions granted by the U.S. Copyright Law is authorized by SPIE subject to payment of copying fees. The Transactional Reporting Service base fee for this volume is $\$ 21.00$ per article (or portion thereof), which should be paid directly to the Copyright Clearance Center (CCC), 222 Rosewood Drive, Danvers, MA 01923. Payment may also be made electronically through CCC Online at copyright.com. Other copying for republication, resale, advertising or promotion, or any form of systematic or multiple reproduction of any material in this book is prohibited except with pemission in writing from the publisher. The CCC fee code is 0277$786 \times / 20 / \$ 21.00$.

Printed in the United States of Americ a by Curran Associates, Inc., under lic ense from SPIE.

Public ation of record for individual papers is online in the SPIE Digital Library.

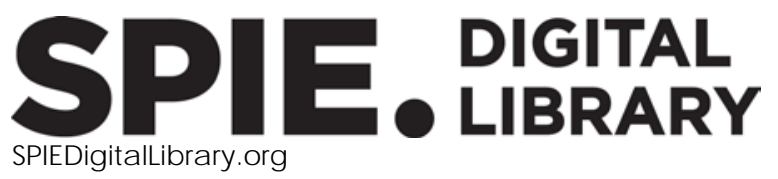

Paper Numbering: Proceedings of SPIE follow an e-First publication model. A unique citation identifier (CID) number is assigned to each article at the time of publication. Utilization of CIDs allows articles to be fully citable as soon as they are published online, and connects the same identifier to all online and print versions of the publication. SPIE uses a seven-digit CID article numbering system structured as follows:

- The first five digits correspond to the SPIE volume number.

- The last two digits indicate publication order within the volume using a Base 36 numbering system employing both numerals and letters. These two-number sets start with $00,01,02,03,04$, 05, 06, 07, 08, 09, 0A, 0B ... 0Z, followed by 10-1Z, 20-2Z, etc. The CID Number appears on each page of the manuscript. 


\section{Contents}

LASER ADDITIVE MANUFACTURING, WEIDING, AND CUTING I

1154604 Experimental investigation on fiber laser c utting carbon fiber reinforced plastics [11546-3]

1154605 Design of semic onductor laser multi-point beam based on laser welding of galvanized sheet [11546-4]

ULTRAFASTLASER PROC ESSING, LASER MICRO, AND NANOFABRICATION I

11546 OE Direct laser selective texturing to improve stainless steel surface condensation heat transfer without any chemical treatment [11546-14]

11546 OG Numerical investigation of hybrid pumped picosecond $\mathrm{CO}_{2}$ amplifier [11546-16]

ULTRAFASTLASER PROC ESSING, LASER MIC RO, AND NANOFABRICATION II

11546 ol Application of femtosecond laser in quartz tuning device mic roprocessing [11546-18]

11546 OK Investigation on single-pulse $266 \mathbf{~ n m}$ nanosecond laser and $780 \mathbf{~ n m}$ femtosecond laser ablation of sapphire [11546-20]

11546 OL Laser shock peening on high-strength steel [11546-21]

\section{POSTER SESSION}

11546 OM A study of laser direct-part marking of 2D code on the aviation aluminum alloy part [11546-22]

$1154600 \quad$ Borosilicate glass drilling by longitudinally excited CO2 laser[11546-24]

11546 OP Observation of using laser direct writing to fabricate nano-grooves on GaAs substrate [11546-25] 
11546 OQ Single and multi-pulse 266nm nanosecond solid-state laser ablation of SiC [11546-26]

$115460 \mathrm{~V}$ Monte Carlo simulation of modulation of randomly rough surfaces to linearly polarized lights [11546-32]

11546 OW Design of an adjustable spot size laser cladding optical system [11546-33] 